\title{
KẾT QUẢ CAN THIỆP NỘI MẠCH CẤP CÚU ĐIỀU TRI Vỡ PHÌNH ĐộNG MẠCH CHỦ NGỰC ĐOẠN XUỐNG
}

Trần Quyết Tiến*, Phan Duy Kiên*

\section{TÓM TẮT}

Đặt vấn đề: Vỡ phình động mạch chủ ngực đoạn xuống là bệnh cảnh cấp cứu nguy hiểm có tỷ lệ tử vong rất cao nếu không điều trị kịp thời. Can thiệp nội mạch hiện được xem là phương pháp điều trị có hiệu quả, ít xâm lấn tại nhiều trung tâm mạch máu trên thế giới.

Mục tiêu nghiên cứu: Đánh giá hiệu quả của can thiệp cấp cứu đặt stent graft trong điều trị vỡ phình động mạch chủ ngực đoạn xuống tại khoa Phẫu thuật Mạch máu bệnh viện Chợ Rẫy.

Đối tượng và phương pháp nghiên cứu: Nghiên cứu mô tả hàng loạt ca với 31 bệnh nhân có bệnh lý động mạch chủ được can thiệp cấp cứu đặt stent graft từ tháng $05 / 2012$ đến tháng 12/2019 tại khoa Phẫu thuật Mạch máu bệnh viện Chợ Rẫy.

Kết quả: Nghiên cứu có 31 bệnh nhân, nam giới chiếm $80,7 \%$, tuổi trung bình là $64 \pm$ 15,1 . Thời gian theo dõi trung bình là 18,6 tháng. Tỷ lệ chuyển vị các nhánh động mạch nuôi tạng và động mạch trên quai động mạch chủ để có vùng hạ đặt ống ghép thích hợp là $12,9 \%$, tỷ lệ phủ động mạch dưới đòn trái là $29 \%$, tỷ lệ gây tê tại chỗ 38,8 \%. Tỷ lệ bung ống ghép thành công là $100 \%$. Tỷ lệ tử vong chu phẫu và trung hạn lần lượt là $6,4 \%$ và $31 \%$. Về biến chứng liên quan đến kỹ thuật sau 30 ngày, chúng tôi ghi nhận có 6 trường hợp rò ống ghép loại II nhưng không trường hợp nào cần can thiệp lại, có 1 trường hợp rò ống ghép thực quản tử vong do nhiễm trùng huyết, 1 trường hợp vỡ túi phình do tăng kích thước túi phình trong thời gian theo dõi

Kết luận: Can thiệp cấp cứu đặt stent graft điều trị vỡ phình động mạch chủ ngực đoạn xuống là phương pháp mới an toàn, hiệu quả, thực hiện nhanh, ít xâm lấm, có tỷ lệ thành công cao và tỷ lệ biến chứng thấp.

Tù khóa: stent graft, võ phình động mạch chủ ngục động xuống, can thiệp cấp cưu.

\section{RESULTS OF EMERGENCY INTERVENTION FOR RUPTURED DESCENDING THORACIC ANEURYSMS}

\section{ABSTRACT:}

Background: Ruptured descending thoracic aortic aneurysm is dangerous with many severe complications and high mortality if untreated. Endovascular is currently considered as an efficent, less invasive treatment in many worldwide vascular surgery centers.

Objective: Evaluating efficacy of stent graft treatment in patients with ruptured descending thoracic aortic aneurysms at Vascular Surgery department, Cho Ray hospital.

Methods: Case series with 31 patients with ruptured descending thoracic aortic aneurysms treated by stent graft at Vascular Surgery department, Cho Ray hospital from 05/2012 to 12/2019.

Results: 31 patients were treated with stent graft for ruptured descending thoracic aneurysms. The mean age was $64 \pm 15,1,80,7 \%$ were men, mean follow-up time was 18,6 months. The rate of patients needed aortic arch and visceral debranching to have sufficent sealing zone was $12,9 \% .29 \%$ of patients had subclavian arterial coverage. The rate of local

\footnotetext{
* Khoa Phẫu thuật Mạch máu, Trung tâm Tim mạch BV Chơ Rẫy Nguoòi chịu trách nhiệm khoa họ: PGS.TS Trần Quyết Tiến

Ngày nhận bài: 31/12/2020 - Ngày Cho Phép Đăng: 22/01/2021
} 
anesthesia was $38,8 \%$. Perioperative and midterm mortality rates were $6,4 \%$ and $31 \% .100$ $\%$ cases were successfully deployed. Technical related complications were type II endoleak (6 cases but none of that needed to re-intervention), 1 case of secondary aorto-esophageal fistula died due to sepsis and 1 case of secondary rupture due to aneurysm expansion.

Conclusion: Endograft therapy for ruptured descending thoracic aneurysms is safe, efficient, less invasive with high success and low complication rate.

Key words: stent graft, ruptured descending thoracic aneurysms, emergency intervention.

\section{ĐẠT VẤN ĐỀ}

Phình động mạch chủ ngực (ĐMCN) được định nghĩa khi kích thước ĐMCN tăng hơn 1,5 lần kích thước ĐMCN bình thường. Theo số liệu của trung tâm kiểm soát và phòng ngừa dịch bệnh Hoa Kỳ, bệnh chiếm tỷ lệ 10,4/100000 dân, hàng năm có gần $13000 \mathrm{BN}$ tử vong vì phình ĐMCN, trong đó nguyên nhân tử vong hàng đầu là do vỡ phình động mạch chủ (ĐMC) [1]. Bệnh nhân vào viện trong bệnh cảnh cấp cứu vỡ phình động mạch chủ nếu không được điều trị kịp thời, tỷ lệ tử vong gần như $100 \%$. Trước đây, điều trị phình ĐMCN vỡ chủ yếu là phẫu thuật cấp cứu thay đoạn phình bằng ống ghép nhân tạo với tỷ lệ tử vong và biến chứng sau mổ cao, thời gian nằm hồi sức và nằm viện lâu. Tại các trung tâm mạch máu lớn trên thế giới, tỷ lệ tử vong sau mổ mở phình ĐMCN là $13,1 \%$, tỷ lệ liệt tuỷ sau mổ là 510\% [2]. Năm 1994, bác sĩ Michael Dake ở trường đại học Stanford, Hòa Kỳ và cộng sự đã báo cáo những trường hợp đầu tiên được điều trị phình ĐMCN đoạn xuống bằng phương pháp can thiệp đặt ống ghép nội mạch[3]. Tiếp nối sau đó, Semba và cộng sự thực hiện ca can thiệp nội mạch đầu tiên điều trị một trường hợp phình động mạch chủ ngực đoạn xuống vỡ năm 1997[4]. Kết quả ban đầu của các nghiên cứu cho thấy can thiệp đặt ống ghép nội mạch có tỷ lệ tử vong chu phẫu thấp hơn và thời gian nằm viện ngắn hơn so với mổ mở kinh điển. Từ đó đến nay, phương pháp này ngày càng phát triển rộng rãi trên thế giới trong điều trị phình ĐMCN, ngay cả trong trường hợp phình vỡ. Nhiều nghiên cứu trên thế giới cho thấy can thiệp đặt ống ghép nội mạch có tỷ lệ tử vong chu phẫu thấp hơn và kết quả ngắn hạn, trung hạn tốt hơn so với mổ mở $[2,5]$.

Tại Việt Nam, can thiệp đặt ống ghép nội mạch đã được triển khai bước đầu tại một số trung tâm phẫu thuật tim mạch ở thành phố Hồ Chí Minh và Hà Nội như bệnh viện Chợ Rẫy, Bạch Mai, Viện tim mạch quốc gia, bệnh viện đại học Y dược thành phố Hồ Chí Minh[6, 7]. Tại bệnh viện Chợ Rẫy, can thiệp đặt ống ghép nội mạch điều trị phình ĐMCN được triển khai từ năm 2012. Trong thời gian đầu, phương pháp này chủ yếu thực hiện trên những bệnh nhân được mổ chương trình. Sau đó, chúng tôi đã thực hiện kỹ thuật này ở những bệnh nhân phình vỡ cần can thiệp cấp cứu nếu đặc điểm hình thái túi phình phù hợp. Việc theo dõi sau can thiệp nội mạch rất quan trọng nhằm đánh giá kết quả và phát hiện sớm những biến chứng liên quan đến kỹ thuật. Chúng tôi thực hiện nghiên cứu này nhằm đánh giá hiệu quả của phương pháp đặt stent graft điều trị bệnh lý động mạch chủ trong bệnh cảnh cấp tính.

\section{ĐỐI TƯợNG VÀ PHƯƠNG PHÁP NGHIÊN CÚU}

\section{Đối tượng nghiên cứu}

Từ tháng 5/2012 đến tháng 12/2019 chúng tôi chọn những bệnh nhân vỡ phình động mạch chủ ngực đoạn xuống nhập viện bệnh viện Chợ Rẫy. Tiêu chuẩn chẩn đoán vỡ phình động mạch chủ ngực đoạn xuống khi có hình ảnh mất liên tục thành động mạch chủ kèm theo hình ảnh tràn máu trung thất, tràn máu màng phổi trên phim chụp cắt lớp điện toán. 


\section{Phương pháp nghiên cứu}

Hồi cứu mô tả hàng loạt ca. Chúng tôi thu thập các dữ liệu về lâm sàng, cận lâm sàng, hình ảnh cắt lớp điện toán, hình ảnh can thiệp trong quá trình đặt stent graft, liên lạc với thân nhân và bệnh nhân qua điện thoại sau xuất viện để thu thập số liệu. Trong can thiệp, chúng tôi ghi nhận thời gian, số lượng máu mất, phương pháp vô cảm, hình ảnh ngay sau can thiệp. Sau can thiệp và tái khám, theo dõi các biến chứng liên quan như rò ống ghép, di lệch ống ghép, xoắn vặn ống ghép, nhiễm trùng ống ghép và tổn thương động mạch đường vào. Các biến chứng nghiêm trọng như tử vong, nhồi máu cơ tim, liệt tủy, suy thận, suy hô hấp, bóc tách ngược Stanford A cũng được ghi nhận. Tiêu chuẩn thành công khi đặt ống ghép vào đúng vị trí tổn thương và không xảy ra các biến chứng sau: tử vong, rò ống ghép loại I và loại III, di lệch ống ghép trên $10 \mathrm{~mm}$, đường kính túi phình tăng trên $5 \mathrm{~mm}$, vỡ túi phình, chuyển mổ mở, nhiễm trùng ống ghép.

\section{Xử lý số liệu}

Sử dụng phần mềm SPSS 20 và các phép thống kê mô tả để phân tích các biến số.

\section{KẾT QUẢ NGHIÊN CÚU}

Từ tháng 05/2012 đến 12/2019, chúng tôi 31 bệnh nhân vỡ phình động mạch chủ ngực đoạn xuống được can thiệp cấp cứu đặt stent graft tại khoa Phẫu thuật Mạch máu bệnh viện Chợ Rẫy. Nam giới chiếm $80,7 \%$, tuổi trung bình là $64,12 \pm$ 15,1 . Thời gian theo dõi trung bình là 18,6 tháng.

\section{3. Đặc điểm lâm sàng và kỹ thuật can thiệp}

Trong 31 trường hợp, chúng tôi ghi nhận đa số có triệu chứng đau ngực khi nhập viện (77,8\%), ngoài ra đặc biệt 4 trường hợp $(12,9 \%)$ có biểu hiện choáng mất máu lúc nhập cấp cứu. Về kỹ thuật can thiệp, chúng tôi có 4 trường hợp $(12,9 \%)$ phải chuyển vị động mạch trên quai động mạch chủ và 9 trường hợp $(29 \%)$ che phủ chủ ý động mạch dưới đòn trái để có vùng hạ đặt ống ghép thích hợp. Về phương pháp vô cảm, tỷ lệ gây tê tại chỗ là $38,8 \%$.

Bảng 1: Đặc điểm nhóm nghiên cưu

\begin{tabular}{|l|c|c|}
\hline \multicolumn{1}{|c|}{ Đặc điểm } & Số bệnh nhân (n=31) & Tỷ lệ (\%) \\
\hline Tuổi trung bình & $64,12 \pm 15,1$ & 80,7 \\
\hline Giới nam & 25 & 64,5 \\
\hline Hút thuốc lá & 20 & 87,1 \\
\hline Tăng huyết áp & 27 & 61,2 \\
\hline Bệnh mạch vành & 19 & 22,5 \\
\hline Hẹp động mạch cảnh & 7 & 61,2 \\
\hline Rối loạn lipid máu & 19 & 35,4 \\
\hline Đái tháo đường & 11 & 77,4 \\
\hline Triệu chứng nhập viện & 24 & 19,3 \\
Đau ngực & 6 & 3,2 \\
Khó thở & 1 & 12,9 \\
Ho ra máu & 4 & 48,3 \\
Choáng mất máu & 15 & \\
Tràn máu màng phổi & & \\
\hline
\end{tabular}


Bảng 2: Đặc điểm phương pháp can thiệp đặt ống ghép nội mạch

\begin{tabular}{|l|c|c|}
\hline \multicolumn{1}{|c|}{ Đặc điểm can thiệp } & $\begin{array}{c}\text { Số bệnh nhân } \\
(\mathbf{n = 3 1})\end{array}$ & Tỷ lệ (\%) \\
\hline Phương pháp vô cảm & 19 & 61,2 \\
Mê nội khí quản & 12 & 38,8 \\
Tê tại chỗ & 4 & 12,9 \\
\hline Chuyển vị các nhánh ĐM trên quai ĐMC & 0 & 0 \\
ĐM dưới đòn trái & 4 & 12,9 \\
ĐM dưới đòn trái, cảnh chung trái & 0 & 0 \\
ĐM dưới đòn trái, cảnh chung trái, cảnh chung phải & 9 & 29 \\
Che phủ động mạch dưới đòn trái & 1 & 3,2 \\
Che phủ động mạch thân tạng & 3 & 9,6 \\
Tạo đường dẫn do đường kính động mạch chậu nhỏ & & \\
\hline
\end{tabular}

\section{Kết quả chu phẫu và kết quả trung hạn}

Bảng 3: Kết quả can thiệp

\begin{tabular}{|l|c|c|}
\hline & Số bệnh nhân (n=31) & Tỷ lệ (\%) \\
\hline Bung ống ghép thành công & 31 & 100 \\
\hline Chuyển mổ mở & 0 & 0 \\
\hline Tử vong trong khi can thiệp & 0 & 0 \\
\hline Tai biến trong can thiệp & 0 & 0 \\
Vỡ ĐMC & 0 & 0 \\
Bóc tách ĐMC & 1 & 3,2 \\
Tổn thương ĐM đường vào & 0 & 0 \\
Lấp ĐM nuôi não ngoài ý muốn & 0 & 0 \\
Lấp ĐM nuôi tạng gây thiếu máu tạng & & \\
\hline
\end{tabular}

Trong thời gian chu phẫu, chúng tôi ghi nhận 2 trường hợp tử vong do nhồi máu cơ tim. Tỷ lệ bung ống ghép thành công là $100 \%, 1$ trường hợp bị tổn thương động mạch đường vào, được phát hiện kịp thời và khâu cầm máu thành công.

Đến tháng 12/2019, thời gian theo dõi trung bình là 18,6 tháng. Trường hợp được theo dõi lâu nhất là 54 tháng, ngắn nhất là 2 tháng. Ngoại trừ 2 trường hợp tử vong chu phẫu, các trường hợp còn lại được tái khám và theo dõi định kỳ đầy đủ. Hình ảnh sau can thiệp được so sánh cẩn thận với hình ảnh trước mổ nhằm phát hiện những biến chứng liên quan đến kỹ thuật đặt ống ghép. Trong quá trình theo dõi, chúng tôi ghi nhận thêm 9 trường hợp tử vong, trong đó 6 ca do nhồi máu cơ tim, 1 ca do nhiễm trùng huyết, rò động mạch chủ thực quản, 2 ca do viêm phổi. 
Bảng 4: Tỷ lệ tử vong và các biến chứng sau hơn 30 ngày

\begin{tabular}{|l|c|c|}
\hline \multicolumn{1}{|c|}{ Biến chứng } & Số bệnh nhân (n=29) & Tỷ lệ (\%) \\
\hline Tử vong & 9 & 31 \\
\hline Nhồi máu cơ tim & 6 & 20,6 \\
\hline Đột quỵ & 3 & 10,3 \\
\hline Suy thận cần điều trị thay thế thận & 0 & 0 \\
\hline Viêm phối, suy hô hấp cần thở máy & 2 & 6,8 \\
\hline Yếu hoặc liệt hai chi dưới & 2 & 6,8 \\
\hline Rò động mạch chủ thực quản & 1 & 3,4 \\
\hline Thiếu máu nuôi tạng và chi & 0 & 0 \\
\hline Vỡ túi phình sau lần đầu can thiệp & 1 & 3,4 \\
\hline Can thiệp lại & 0 & 0 \\
\hline
\end{tabular}

Tất cả 29 trường hợp theo dõi được chụp cắt lớp điện toán kiểm tra. 28 trường hợp $(96,5 \%)$ thấy túi phình giảm hoặc không tăng kích thước, 1 trường hợp túi phình tăng kích thước hơn $>10$ mm ở tháng thứ 6 sau can thiệp nhưng không rõ loại rò ống ghép, bệnh nhân này sau đó tử vong do vỡ túi phình và viêm phổi. Ngoài ra, trong nghiên cứu còn ghi nhận 6 trường hợp rò ống ghép loại II từ ĐM dưới trái. Trong quá trình theo dõi, hình ảnh rò loại II vẫn còn tồn tại nhưng kích thước túi phình không tăng thêm. Đặc biệt trong nghiên cứu, chúng tôi ghi nhận 1 ca rò động mạch chủ thực quản, biến chứng xuất huyết tiêu hoá, nhiễm trùng huyết và tử vong ở tháng thứ 6 .

Bảng 5: Tỷ lệ biến chứng liên quan đến kỹ thuật can thiệp sau hơn 30 ngày

\begin{tabular}{|l|c|c|}
\hline \multicolumn{1}{|c|}{ Biến chứng liên quan kỹ thuật can thiệp } & Số bệnh nhân $(\mathbf{n}=\mathbf{2 9})$ & Tỷ lệ (\%) \\
\hline Rò ống ghép & 0 & 0 \\
Loại I & 6 & 20,6 \\
Loại II & 0 & 0 \\
Loại III & 0 & 0 \\
Loại IV & 0 & 0 \\
Loại V & 1 & 3,4 \\
\hline Tăng đường kính túi phình $>5 \mathrm{~mm}$ & 1 & 3,4 \\
\hline Rò ống ghép - thực quản & & \\
\hline
\end{tabular}

\section{BÀN LUẬn}

thiệp

\section{a. Đặc điểm lâm sàng và kỹ thuật can}

Nghiên cứu của chúng tôi gồm 31 vỡ phình động mạch chủ ngực đoạn xuống được cán thiệp nội mạch cấp cứu, nam giới chiếm ưu thế giống như các nghiên cứu khác trên thế giới. Về đặc điểm lâm sàng, hầu hết trường hợp nhập viện trong bệnh cảnh huyế động còn ổn định, chỉ có
4/31 trường hợp choáng mất máu. Vỡ phình động mạch chủ ngực đoạn xuống thường có 3 dạng: dạng vỡ tự do, vỡ trong bao khu trú và dạng đe doạ, tiến triển. Dạng vỡ tự do thường bệnh nhân mất máu rất nhanh vào khoang màng phổi trái và đa số tử vong trước lúc nhập viện [8]. Một loại vỡ hay gặp trong hầu hết các nghiên cứu là vỡ khu trú biểu hiện trên hình ảnh chụp cắt lớp điện toán là tụ dịch trung thất đậm độ cao. Các dạng vỡ có 
biểu hiện tràn máu màng phổi là dạng đe doạ tiến triển và cần can thiệp khẩn cấp. Một ưu điểm của can thiệp nội mạch so với mổ mở trong điều trị bệnh lý động mạch chủ là bệnh nhân có thể không cần gây mê toàn thân. Trên thế giới có nhiều nghiên cứu so sánh kết quả của các phương pháp vô cảm trong can thiệp đặt ống ghép nội mạch. Kết quả của nhiều nghiên cứu cho thấy không có sự khác biệt trong tỷ lệ tử vong chu phẫu giữa các phương pháp vô cảm [9]. Tuy nhiên, nhiều tác giả lại khuyến cáo gây mê toàn thân trong đặt stent graft vì phương pháp gây mê giúp phẫu thuật viên kiểm soát dễ dàng huyết áp trong lúc bung ống ghép. Không những thế, gây mê toàn thân giúp $\mathrm{BN}$ nằm yên trong lúc thao tác, điều này tránh việc tăng huyết áp do cường giao cảm khi đau và tránh được những tổn thương $\mathrm{M}$ đường vào trong lúc can thiệp. Mặc dù vậy, ở những BN nguy cơ cao như lớn tuổi, có nhiều bệnh lý nặng đi kèm và vỡ túi phình, đặc biệt trong trường hợp cấp cứu, phương pháp gây tê tại chỗ được khuyến cáo sử dụng nhiều hơn vì giúp $\mathrm{BN}$ tránh được tác dụng phụ của thuốc mê và biến chứng suy hô hấp sau mổ. Ngoài ra, khi gây tê tại chỗ $\mathrm{BN}$ không cần phải nằm nghiêng kê tư thế, một việc có thế ảnh hưởng và làm nặng hơn tình trạng vỡ túi phình. Trong nghiên cứu này, chúng tôi ghi nhận 38,8\% bệnh nhân được gây tê tại chỗ, tất cả trường hợp này được can thiệp thành công. Những trường hợp gây mê đa phần là do bệnh nhân cần mổ mở làm chuyển vị động mạch trên quai hoặc bệnh già yếu không hợp tác.

Trong can thiệp động mạch chủ ngực, một vấn đề hay gặp là chuyển vị các nhánh ĐM trên quai ĐMC ngực. Việc chuyển vị là bắt buộc nếu chiều dài đầu gần nhỏ hơn $20 \mathrm{~mm}$ nhằm tạo $\mathrm{ra}$ vùng hạ đặt thích hợp cho stent garft. Nghiên cứu của chúng tôi ghi nhận có 4 ca phình động mạch chủ ngực vỡ có vùng hạ đặt ở vùng 1 nên bắt buộc phải chuyển vị động mạch cảnh chung trái và dưới đòn trái để có chiều dài vùng hạ đặt thích hợp. Riêng các trường hợp có vùng hạ đặt nằm trong vùng 2 , chúng tôi quyết định che phủ ĐM dưới đòn trái không kèm chuyển vị. Tỷ lệ che phủ ĐM dưới đòn trái của nghiên cứu chiếm tỷ lệ đáng kể $29 \%$. Trong can thiệp đặt stent graft, nếu vùng hạ nằm trong vùng 2 , việc che phủ ĐM dưới đòn trái có thể được thực hiện mà không cần phải chuyển vị ĐM dưới đòn trái vào $\mathrm{ĐM}$ cảnh chung trái, điều này làm giảm đáng kể thời gian cuộc mổ do không phải mất thời gian mổ mở chuyển vị. Mặc dù vậy, theo khuyến cáo của hiệp hội phẫu thuật mạch máu thế giới năm 2009[10], nếu vùng hạ đặt ống ghép nội mạch trong vùng 2 , việc che phủ ĐM dưới đòn trái kèm với chuyển vị nên được thực hiện thường quy trong những trường hợp can thiệp chương trình. Tuy nhiên, nếu trong trường hợp nguy cơ phẫu thuật cao và cần can thiệp cấp cứu, việc che phủ $Đ M$ dưới đòn trái không kèm chuyển vị có thể chấp nhận được mặc dù nguy cơ đột quỵ và thiếu máu nuôi tay trái sau mổ cao hơn so với che phủ có kèm theo chuyển vị. Mặc dù vậy, các nghiên cứu trên thế giới đều đưa ra chỉ định tuyệt đối của chuyển vị khi che phủ ĐM dưới đòn trái trong những trường hợp sau [10]:

-Bệnh nhân đã bắc cầu mạch vành và có sử dụng ĐM vú trong trái làm cầu nối.

- Bệnh nhân suy thận mạn được phẫu thuật làm shunt động - tĩnh mạch trái để chạy thận.

-Bệnh nhân đã được phẫu thuật thay ĐMC bụng dưới thận.

- Tắc hoặc hẹp ĐM đốt sống phải.

- Tắc ĐM chậu trong hai bên.

\section{b. Kết quả chu phẫu và trung hạn}

Về tỷ lệ tử vong chu phẫu và sau 30 ngày, nghiên cứu của chúng tôi có kết quả là $6,4 \%$ và $31 \%$, tương đương với nhiều nghiên cứu của một số tác giả nhu Jonker, Hammo [11, 12]. 2 trường hợp tử vong chu phẫu đều không liên quan đến túi phình (nhồi máu cơ tim). 6/9 trường hợp tử vong sau 30 ngày cũng do nguyên nhân nhồi máu cơ tim, 1 trường hợp do viêm phổi và 2 trường hợp tử vong liên quan đến túi phình. Đặc điểm của bệnh nhân can thiệp động mạch chủ là bệnh nhân thường lớn tuổi, có nhiều bệnh lý nội khoa đi kèm, ngoài ra bệnh lý mạch máu là bệnh lý hệ thống nên biến cố tim mạch là nguyên nhân tử vong hàng đầu sau can thiệp theo nhiều nghiên cứu. Trong trường hợp can thiệp cấp cứu, tầm 
soát bệnh lý mạch vành không thể thực hiện thường quy giống như can thiệp chương trình nên nguy cơ tim mạch sau mổ là rất lớn. Tuy cỡ mẫu của chúng tôi còn nhỏ nhưng kết quả này cũng cho thấy phương pháp can thiệp đặt stent graft có kết quả tỷ lệ tử vong chu phẫu thấp giống như một số nghiên cứu khác trên thế giới nếu so sánh với phương pháp mổ kinh điển [11-13] .

Về biến chứng liên quan đến kỹ thuật, rò ống ghép là loại biến chứng hay gặp và được quan tâm nhất sau can thiệp động mạch chủ. Sau 30 ngày theo dõi, nghiên cứu của chúng tôi không ghi nhận trường hợp nào rò ống ghép loại I nhưng có 6 trường hợp $(20,6 \%)$ rò ống ghép loại II. Nguyên nhân do tỷ lệ che phủ dưới đòn trái của nghiên cứu đáng kể nên sẽ có rò ống ghép loại II từ động mạch dưới đòn trái. Cũng như nhiều nghiên cứu khác trên thế giới, chúng tôi chỉ đặt vấn đề can thiệp lại trong rò ống ghép loại II khi túi phình tăng kích thước trên $5 \mathrm{~mm}$ trong vòng 6 tháng hoặc trên $10 \mathrm{~mm}$ khi phát hiện ở bất kỳ thời điểm nào [14]. Sau khi theo dõi hơn 1 năm, chúng tôi nhận thấy tất cả trường hợp rò ống ghép loại II không tăng kích thước nên không can thiệp gì thêm. Ngoài biến chứng rò ống ghép, nghiên cứu của chúng tôi đặc biệt ghi nhận 1 trường hợp rò động mạch chủ-thực quản thứ phát. Theo $\mathrm{y}$ văn, đây là loại biến chứng rất nặng nề, chiếm tỷ lệ từ $1,7-1,9 \%$ [15]. Trường hợp của nghiên cứu là một bệnh nhân 51 tuổi, có tiền căn ghép thận tự thân, đang dùng thuốc ức chế miễn dịch kéo dài 4 năm. Bệnh nhân được can thiệp cấp cứu do có túi phình động mạch chủ ngực xuống dạng túi vỡ nghi do nhiễm trùng. Mặc dù được can thiệp thành công và phát hiện kịp thời biến chứng rò động mạch chủ thực quản nhưng bệnh nhân tử vong do nhiễm trùng huyết nghĩ do suy giảm miễn dịch nặng ở tháng thứ 6 . Nhiều tác giả cho rằng có 2 giả thuyết gây nên biến chứng rò động mạch chủ thực quản sau đặt ống ghép nội mạch. Nguyên nhân thứ nhất là do lực ly tâm của ống ghép nội mạch tác động làm ăn mòn thành động mạch chủ. Nguyên nhân thứ hai là do nhiễm trùng gây ra phản ứng viêm, gây loét thành động mạch chủ và thực quản. Ở bệnh nhân của chúng tôi có hai yếu tố thuận lợi trên, đặc biệt là yếu tố nhiễm trùng do suy giảm miễn dịch sau một thời gian dài phải dùng thuốc ức chế miễn dịch. Để điều trị rò động mạch chủ- thực quản, nhiều tác giả đề nghị phẫu thuật làm sạch ổ nhiễm trùng, lấy bỏ ống ghép, xử lý tổn thương thực quản và dùng kháng sinh lâu dài. Nếu bệnh nhân có nguy cơ phẫu thuật cao, chúng ta có thể đặt giá đỡ che phủ thực quản để tránh biến chứng xuất huyết tiêu hoá trước, sau đó phẫu thuật triệt để xử lý thương tổn sau. Tuy nhiên, vì đây là phẫu thuật lớn nên tỷ lệ tử vong sau mổ còn cao.
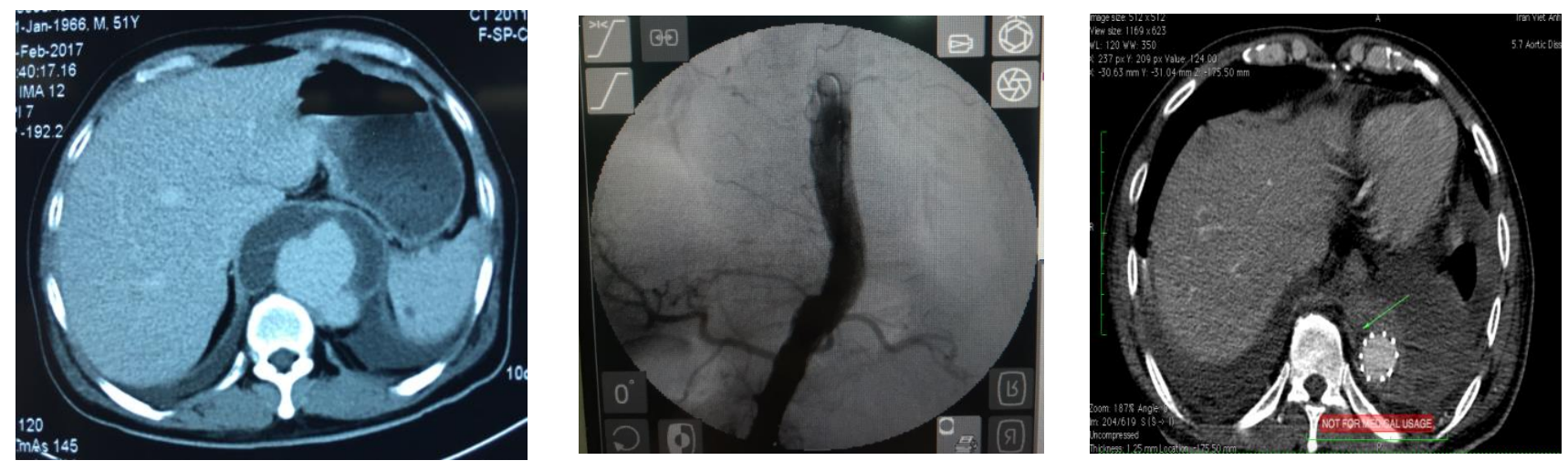

Hình 1: Bệnh nhân T.V.A 61 tuổi, can thiệp đặt stent graft cấp cứu do phình ĐMC ngực võ̃, phát hiện rò động mạch chủ thực quản sau 6 tháng 
Trường hợp vỡ túi phình duy nhất sau can thiệp của nghiên cứu chúng tôi là một trường hợp có tăng đường kính túi phình $>5 \mathrm{~mm}$ nhưng không rõ loại rò ống ghép. Trong thời gian chu phẫu, bệnh nhân tiến triển tốt và chúng tôi không ghi nhận rò ống ghép hay vỡ túi phình. Tuy vậy, $\mathrm{BN}$ này không đi tái khám theo lịch hẹn mà chỉ nhập cấp cứu vào tháng thứ 6 do khó thở và mệt. Sau khi chụp cắt lớp điện toán kiểm tra, chúng tôi phát hiện đường kính túi phình của $B N$ là $140 \mathrm{~mm}$, tăng hơn $10 \mathrm{~mm}$ so với trước can thiệp. Bệnh nhân đột tử do vỡ túi phình trước khi được can thiệp lại. Một số nghiên cứu trên thế giới khi theo dõi sau đặt

a)

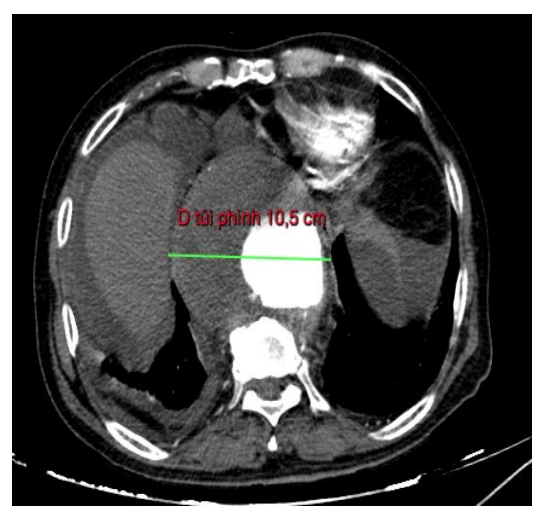

b)

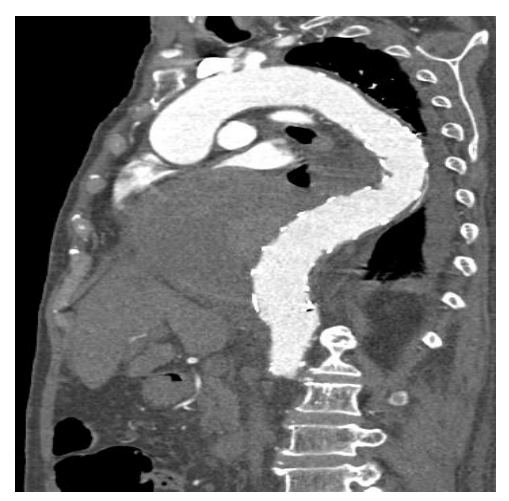

ống ghép nội mạch cũng ghi nhận những trường hợp tăng kích thước túi phình nhưng không rõ loại rò ống ghép. Nhiều tác giả cho rằng những trường hợp này có thể là rò ống ghép loại $\mathrm{V}$, rò dạng thẩm thấu qua ống ghép [16]. Tuy nhiên để khẳng định rò ống ghép loại $\mathrm{V}$ cần nhiều phương tiện chẩn đoán hình ảnh hiện đại hơn để chứng minh. Qua trường hợp tử vong do vỡ túi phình trong nghiên cứu, chúng tôi nhận thấy rằng việc tái khám đầy đủ và theo dõi sát cũng góp phần phát hiện sớm những trường hợp có biến chứng liên quan đến ống ghép để can thiệp kịp thời nhằm ngăn ngừa biến chứng vỡ túi phình.
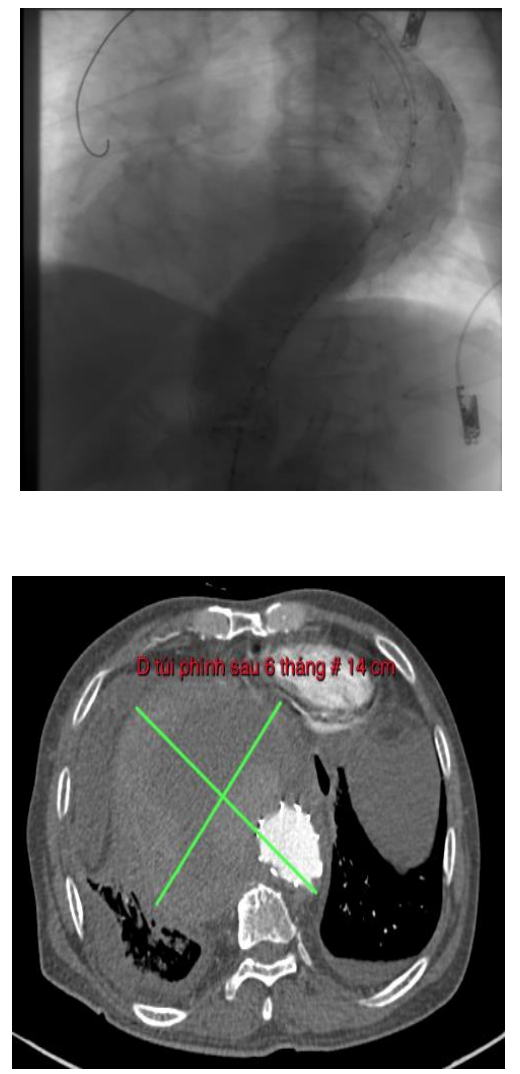

Hình 2: Bệnh nhân tăng kích thuớc túi phình (b) so với sau khi can thiệp (a)

\section{KẾT LUẬN}

Qua 31 bệnh nhân được can thiệp cấp cứu đặt stent graft điều trị vỡ phình động mạch chủ ngực, chúng tôi nhận thấy đây là phương pháp mới an toàn, ít xâm lấn, hiệu quả, có tỷ lệ tử vong chu phẫu thấp, tỷ lệ thành công về mặ kỹ thuật cao. Qua nghiên cứu này, chúng tôi cũng ghi nhận số lượng bệnh nhân can thiệp động mạch 
chủ ngực có vùng hạ đặt ở vùng 2 chiếm tỷ lệ đáng kể, do đó phủ động mạch dưới đòn trái có thể được xem xét trong can thiệp cấp cứu. Ngoài ra, biến cố tim mạch sau can thiệp vẫn là nguyên nhân tử vong hàng đầu, do đó việc khảo sát mạch vành nên được khuyến cáo thực hiện ngay cả trong can thiệp cấp cứu và cần sự phối hợp nhịp nhàng với nhóm chuyên khoa tim mạch can thiệp. Trong quá trình theo dõi, biến chứng liên quan đến ống ghép đáng kể nên cần những nghiên cứu dài hạn hơn để đánh giá đầy đủ hiệu quả của phương pháp này.

\section{TÀI LIỆU THAM KHẢO}

1. Moore, W., Endovascular Suegery 2011: Elsevier Saunders.

2. Swerdlow, N.J., W.W. Wu, and M.L. Schermerhorn, Open and Endovascular Management of Aortic Aneurysms. Circ Res, 2019. 124(4): p. 647-661.

3. Michael, D., Transluminal placement of endovascular stent graft for the treatment of descending thoracic aortic aneurysm. New England Journal Medicine, 1994. 331: p. 1729-1734.

4. Semba, C.P., et al., Acute Rupture of the Descending Thoracic Aorta: Repair with Use of Endovascular Stent-Grafts. Journal of Vascular and Interventional Radiology, 1997. 8(3): p. 337-342.

5. Gopaldas, R.R., et al., Endovascular versus open repair of ruptured descending thoracic aortic aneurysms: a nationwide riskadjusted study of 923 patients. J Thorac Cardiovasc Surg, 2011. 142(5): p. 1010-8.

6. Hiếu, N.L. and T.V. Hoàng, Một số đặc điểm kỹ thuật và kết quả bước đầu của can thiệp đặt stent graft ở bệnh nhân có bệnh lý động mạhc chủ tại viện tim mạch quốc gia Tạp chí $\mathrm{Y}$ học thực hành 2013. 866(4): p. 171-173.

7. Phạm Minh Ánh, P.D.K., Đánh giá kết quả đặt ống ghép nội mạch điều trị bệnh lý động mạch chủ Tạp chí Y học TPHCM, 2017. 21: p. 190.
8. Rajiah, P., CT and MRI in the Evaluation of Thoracic Aortic Diseases. Int $\mathrm{J}$ Vasc Med, 2013. 2013: p. 797189.

9. Hogendoorn, W., et al., Surgical and anesthetic considerations for the endovascular treatment of ruptured descending thoracic aortic aneurysms. Curr Opin Anaesthesiol, 2014. 27(1): p. $12-20$.

10. Matsumura, J.S., A.Z. Rizvi, and S. Society for Vascular, Left subclavian artery revascularization: Society for Vascular Surgery Practice Guidelines. J Vasc Surg, 2010. 52(4 Suppl): p. 65S-70S.

11. Jonker, F.H., et al., Outcomes of endovascular repair of ruptured descending thoracic aortic aneurysms. Circulation, 2010. 121(25): p. 2718-23.

12. Hammo, S., et al., Outcome After Endovascular Repair of Ruptured Descending Thoracic Aortic Aneurysm: A National Multicentre Study. Eur J Vasc Endovasc Surg, 2019. 57(6): p. 788-794.

13. Lee, H.C., et al., Endovascular Repair versus Open Repair for Isolated Descending Thoracic Aortic Aneurysm. Yonsei Med J, 2015. 56(4): p. 904-12.

14. Ameli-Renani, S., V. Pavlidis, and R.A. Morgan, Secondary Endoleak Management Following TEVAR and EVAR. Cardiovasc Intervent Radiol, 2020.

15. Tao, M., et al., Secondary aortoesophageal fistula after thoracic aortic aneurysm endovascular repair treated by covered esophageal stenting. World J Clin Cases, 2016. 4(8): p. 233-7.

16. Harky, A., et al., Ruptured isolated descending thoracic aortic aneurysm: open or endovascular repair? Vessel Plus, 2018. 2(5). 